\title{
Diagnostic Utility of Fine Needle Aspiration Cytology of Sensory Cutaneous Nerve in Leprosy
}

\author{
Naik Reena ${ }^{1}$, Sa Dilip Kumar², Panda Kishori $\mathbf{M}^{1 *}$ \\ 'Dept. of Pathology, Govt Medical College (LSLAMMC), Raigarh, Chhattisgarh. India \\ ${ }^{2}$ Dept of Skin \&VD, Govt Medical College(LSLAMMC), Raigarh, Chhattisgarh, India
}

\begin{abstract}
Background: Peripheral neuropathy is a central feature of leprosy. Intraneural inflammation caused by M. leprae is the morphological hallmark of this disease, FNAC of sensory cutaneous nerve has proved to be a valuable diagnostic tool.

Methods: The data of patients with sensory cutaneous nerve involvement were retrieved from our record for the period from Nov 2014 to Sept 2015. The hematoxylin and eosin (H and E)- and May-Grünwald-Giemsa (MGG) stained slides were screened for Schwann cells, granuloma, and necrosis. Modified Ziehl-Neelsen (ZN) stained smears were searched for single lepra bacilli and globi.

Results: Twenty-five sensory cutaneous nerves were aspirated. Out of which 19 yielded diagnostic aspirate. Five cytologic pictures were seen - epithelioid cell granulomas (6), epithelioid cell granulomas with necrosis (3);necrosis + lepra bacilli (4); only lepra bacilli (2); and lymphocyte \& macrophage infiltrate (4).Following the Ridley-Jopling classification, in our study there were 9 cases of TT, 4 of BT-TT, 1 of BB, 2 of BL, and 3 of LL.
\end{abstract}

Conclusion: FNAC of sensory cutaneous nerve is useful in diagnosis and classification of leprosy on the R-J scale.

Keywords: Peripheral Neuropathy, Fine-Needle Aspiration Cytology, Hansen's Disease, Lepra Bacilli, Sensory Cutaneous Nerve.

\section{Introduction}

Leprosy is a chronic granulomatous infection caused by Mycobacterium leprae, affecting the skin and peripheral nerves and resulting in disabling deformities. ${ }^{[1]}$ Pure neuritic leprosy (PNL) is a type of leprosy, which is clinically limited to peripheral nerves and constitutes $4-8 \%$ of all leprosy. ${ }^{[2]}$.The clinical features of leprosy include anesthetic skin lesions, nerve enlargement, tenderness, pain and sensory motor impairment. These are not specific and may not always be present. So diagnosis remains difficult in early stages of leprosy including PNL cases. It is recommended that sensory cutaneous nerve fine needle aspiration cytology (FNAC) is a feasible, viable, effective, and relatively "nerve sparing" procedure, which can be done routinely as an outdoor procedure in the evaluation of leprosy patients. ${ }^{[3]}$ Only a few studies have evaluated the role of fine needle aspiration cytology (FNAC) in the diagnosis of leprosy, especially in PNL cases. ${ }^{[2]}$ This study was undertaken to evaluate the diagnostic role of nerve FNAC in leprosy and to evaluate the possible utility of cytology in classifying lesions of leprosy on the R-J scale.

\section{Materials and methods}

This retrospective study included leprosy patients attending the outpatient department of our medical college hospital during one-year period from Nov 2014 to Sept 2015.
FNAC was done from the enlarged thickened nerve in 25 cases, where diagnosis of leprosy was suspected clinically including relapse cases. All peripheral and cutaneous nerves were palpated for their number, size, nodularity and tenderness. These findings were entered in a chart. The cases were examined for most prominent site of thickened nerve. The area was cleaned with an alcohol swab. The prominent part of nerve was fixed by index finger and thumb of left hand and FNAC was done using $22 \mathrm{G}$ needle fitted in $10 \mathrm{~mL}$ disposable plastic syringe. The suction was applied and aspiration was performed using a singlepuncture. The direction of the needle was always kept parallel to the length of the nerve so as to cause minimal damage to the nerve. The material aspirated was smeared on glass slides. Minimum three smears were made for each case. The wet smear was fixed in $95 \%$ ethanol and stained by Papanicolaou stain after 30 minutes of fixation. One of the dried smear was stained by Giemsa stain and the other dried smear was stained by modified acid fast bacilli (AFB for Lepra) stain demonstrate AFB. Both Papanicolaou and Giemsa stained smears were examined for cytological details. Smear stained by modified AFB (Lepra) stain was examined for the presence or absence of AFB. If the AFB was seen, it was quantified according to the presence of their number per high-power field. It was denoted as present $(+)$, if occasional bacilli was seen after searching many high- 
power fields, and many $(++)$ if many bacilli per high-power field were seen. Negative finding was denoted as absent (-). Cytological criteria for sub-classification of leprosy were applied as defined by Singh et al ( table 1). ${ }^{[4]}$ Patients were classified according to RJ criteria into tuberculoid (TT), borderline tuberculoid (BT), mid-borderline (BB), borderline lepromatous (BL), and lepromatous (LL) types.

\section{Results}

Out of total 25 cases of FNAC done from sensory cutaneous nerves 19 cases $(76 \%)$ yielded diagnostic aspirates. The sensory cutaneous nerves aspirated are detailed in [Table-2]. Most common nerve affected in the present study was right ulnar nerve. But the most common nerve aspirated was right posterior tibial nerve. Mononeuropathy was seen in 6 cases and polyneuropathy was seen in 13 cases. Affected age group was 20 to 61 years [Table 3].

In cytology smears, in order to ascertain if the aspiration was done from a nerve, a search was made for schwann cells. Schwann cells may be present either singly or in fascicles along with other features like granuloma, necrosis, lymphocytic infiltrate and lepra bacilli [Figure1\& 2].Five cytomorphologic patterns were observed in smears of nerve aspirates[Table 4]. These are inflammation composed of epithelioid cell granulomas (6), epithelioid cell granuloma with necrosis (3); necrosis + lepra bacilli (4); only lepra bacilli (2); and lymphocyte \& macrophage infiltrate (4). Following the Ridley-Jopling classification, in our study there were 9 cases of TT, 4 of BT-TT, 1 of BB, 2 of BL, and 3 of LL.

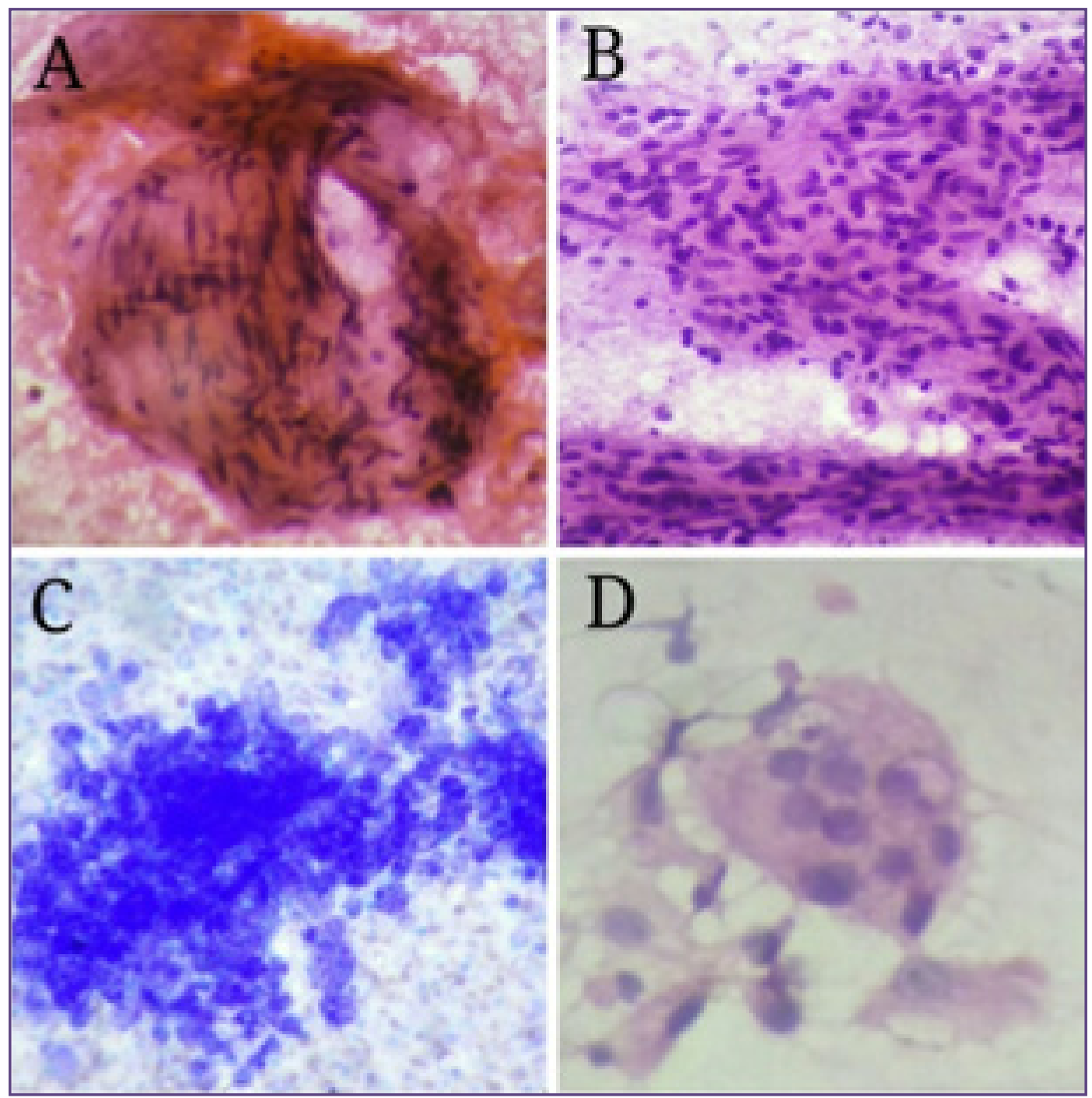

Fig. 1: (A) Showing Schwann cell in fascicle. (B) Epitheloid granuloma. (C) Dense lymphocytic infiltrate. (D) Epitheloid cell with giant cell. 


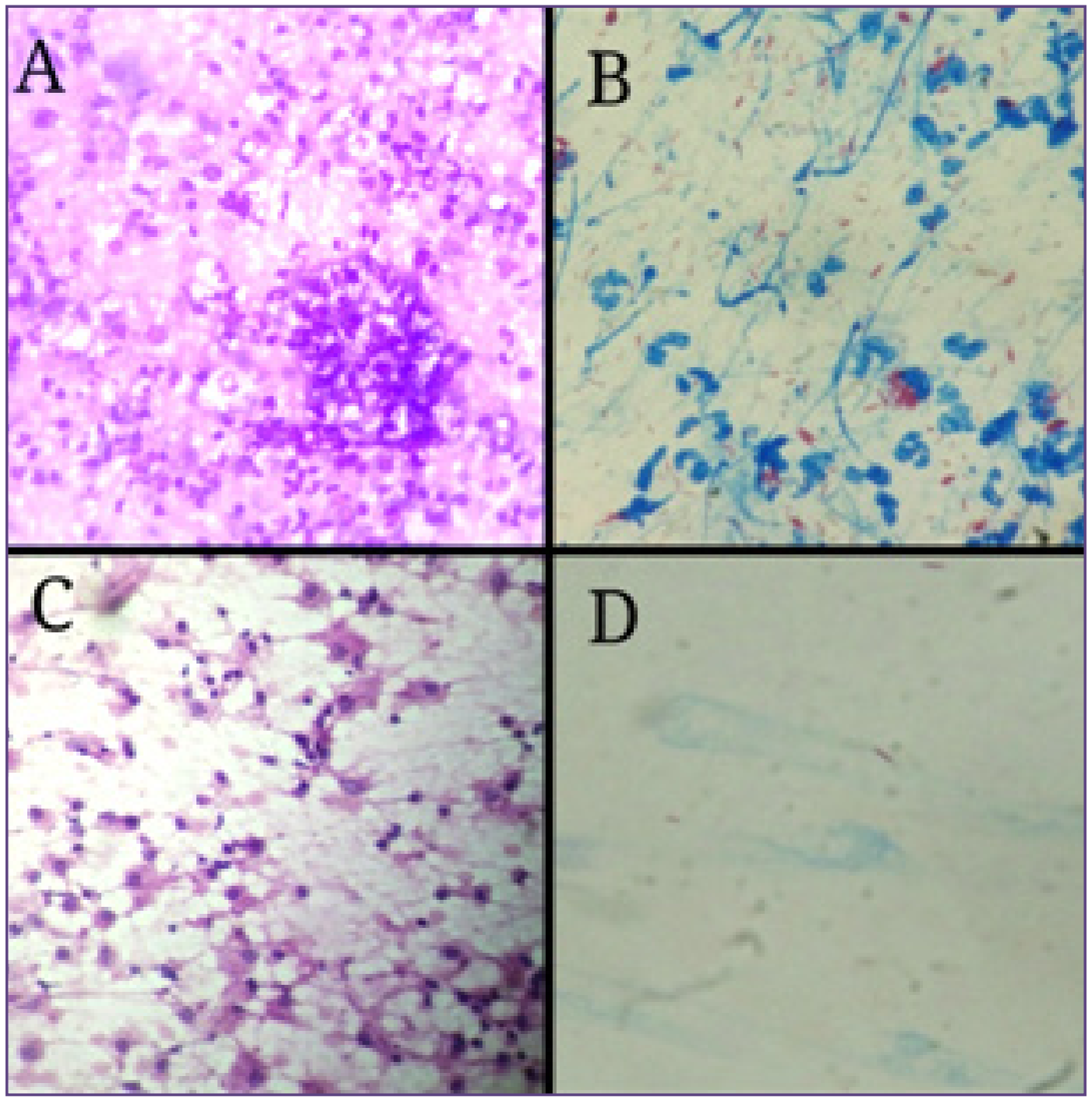

Fig. 2: Microphotographs showing (A) Necrosis. (B) Lepra bacilli in globi. (C) Foamy macrophages. and (D) Singly present lepra bacilli.

Table 1: Cytological criteria (R-J) for sub-classification of leprosy.

\begin{tabular}{|c|c|c|c|c|c|}
\hline Diagnosis & Cellularity & Macrophages & Epitheloid cell granuloma & Lymphocytes & BI \\
\hline $\begin{array}{l}\text { Tuberculoid- Borderline } \\
\text { tuberculoid }\end{array}$ & good & absent & well formed & numerous & 0 \\
\hline Mid borderline & moderate & few & diffuse & few & $1+, 2+$ \\
\hline Borderline lepromatous & fair & fair number & absent & numerous & $3+, 4+$ \\
\hline Lepromatous & heavy & foamy & absent & few & $5+, 6+$ \\
\hline Lepra reaction & - & Neutrophil + & - & Neutrophils + & Fragmented \\
\hline
\end{tabular}

Table 2:Showing details of sensory cutaneous nerve aspirated( $n=19)$

\begin{tabular}{|l|l|}
\hline Sensory Cutaneous nerve aspirated & $\mathrm{n}$ \\
\hline Right posterior tibial nerve & 9 \\
\hline Left posterior tibial nerve & 1 \\
\hline Right radial nerve & 2 \\
\hline
\end{tabular}




\begin{tabular}{|l|c|}
\hline Sensory Cutaneous nerve aspirated & $\mathrm{n}$ \\
\hline Left radial nerve & 3 \\
\hline Left ulnar nerve & 2 \\
\hline Right ulnar nerve & 1 \\
\hline Left common peroneal nerve & 1 \\
\hline TOTAL & 19 \\
\hline
\end{tabular}

Table 3: showing clinical details and cytological diagnosis $(n=19)$

\begin{tabular}{|c|c|c|c|c|c|c|c|}
\hline \multirow{2}{*}{ S.No. } & \multirow{2}{*}{ Age/Sex } & \multicolumn{2}{|c|}{ Involment } & \multirow{2}{*}{ Site of FNAC } & \multirow{2}{*}{ Mono } & \multirow{2}{*}{ Poly } & \multirow{2}{*}{$\begin{array}{l}\text { Cytological } \\
\text { diagnosis }\end{array}$} \\
\hline & & $\mathbf{N}$ & $\mathrm{S}+\mathrm{N}$ & & & & \\
\hline 1 & $40 / F$ & + & - & Rt Post tibial & - & + & BT-TT \\
\hline 2 & $34 / F$ & + & + & Rt Post tibial & - & + & LL \\
\hline 3 & $33 / F$ & + & - & Lt Post tibial & - & + & BT-TT \\
\hline 4 & $22 / \mathrm{M}$ & + & - & Rt Radial & + & - & BB \\
\hline 5 & $38 / \mathrm{M}$ & + & + & Rt Post Radial & - & + & TT \\
\hline 6 & $61 / \mathrm{M}$ & + & + & Rt Post tibial & - & + & $\mathrm{LL}$ \\
\hline 7 & $20 / F$ & + & + & Rt Post tibial & - & + & TT \\
\hline 8 & $31 / \mathrm{M}$ & + & - & Lt ulnar N & + & - & TT \\
\hline 9 & $27 / \mathrm{M}$ & + & + & Rt ulnar & - & + & LL \\
\hline 10 & $38 / \mathrm{M}$ & + & + & Lt ulnar & - & + & $\mathrm{BL}$ \\
\hline 11 & $42 / \mathrm{M}$ & + & + & Rt Post tibial & - & + & TT \\
\hline 12 & $42 / F$ & + & - & Lt commopero & + & - & TT \\
\hline 13 & $42 / F$ & + & - & Rt Post tibial & - & + & TT \\
\hline 14 & $48 / \mathrm{M}$ & + & + & Lt radial & + & - & TT-BT \\
\hline 15 & $25 / \mathrm{M}$ & + & + & Rt Post tibial & + & - & TT-BT \\
\hline 16 & $30 / \mathrm{M}$ & + & + & Lt radial & - & + & TT \\
\hline 17 & $40 / \mathrm{M}$ & + & - & Rt post tibial & + & - & TT \\
\hline 18 & 29/M & + & - & Rt Post tibial & - & + & TT \\
\hline 19 & $22 \mathrm{~m}$ & + & + & Left radial & - & + & $\mathrm{BL}$ \\
\hline
\end{tabular}

Table 4: Showing five cytologic patterns.

\begin{tabular}{|l|c|}
\hline Cytomorphological picture & $\mathbf{n = 1 9}$ \\
\hline Epithelioid cell granuloma only & 6 \\
\hline Granuloma +Necrosis & 3 \\
\hline Necrosis+ lepra bacilli & 4 \\
\hline Only lepra bacilli & 2 \\
\hline Lymphocyte, macrophage infiltration & 4 \\
\hline
\end{tabular}

Table 5: Cytomorphological classification of leprosy according to Ridley-Jopling spectrum.

\begin{tabular}{|l|l|l|l|l|}
\hline Class & $\begin{array}{l}\text { Singh et al. } \\
\text { (skin smear) }\end{array}$ & $\begin{array}{l}\text { Prasad PV et al. }{ }^{[19]} \\
\text { (skin smear) }\end{array}$ & $\begin{array}{l}\text { Jaswal et al. }{ }^{[20]} \\
\text { (skin smear) }\end{array}$ & Vijaikumar et al. ${ }^{[15]}$ (nerve aspirate) \\
\hline TT & $\begin{array}{l}\text { Cellular smears, cohesive } \\
\text { epithelioid cell granulomas, } \\
\text { numerous lymphocytes not } \\
\text { infiltrating the granuloma, } \\
\text { no stainable AFB }\end{array}$ & $\begin{array}{l}\text { Cellular material with } \\
\text { predominantly lymphocyte } \\
\text { population and histiocytes } \\
\text { without epithelioid } \\
\text { transformation, no stainable } \\
\text { AFB }\end{array}$ & $\begin{array}{l}\text { Cellular smears, } \\
\text { cohesive epithelioid cell } \\
\text { granulomas, numerous } \\
\text { lymphocytes not } \\
\text { infiltrating the granuloma. } \\
\text { BI 0-3+ }\end{array}$ & $\begin{array}{l}\text { Good cellular aspirate } \text { Cohesive } \\
\text { epithelioid cell granuloma or lymphocytic } \\
\text { cell collection } \text { Predominantly epithelioid } \\
\text { cells with predominant to moderate } \\
\text { number of lymphocytes. Occasional } \\
\text { giant cells and neutrophils } \cdot \text { BI 0-1+. }\end{array}$ \\
\hline BT & Same as TT & $\begin{array}{l}\text { Cellular material with } \\
\text { lymphocytes, histiocytes } \\
\text { and epithelioid cells, foamy } \\
\text { macrophages are not a } \\
\text { feature, no stainable AFB. }\end{array}$ & Same as TT & Same as TT \\
\hline
\end{tabular}




\begin{tabular}{|c|c|c|c|c|}
\hline Class & $\begin{array}{l}\text { Singh et al. }{ }^{[4]} \\
\text { (skin smear) }\end{array}$ & $\begin{array}{l}\text { Prasad PV et al. }{ }^{[19]} \\
\text { (skin smear) }\end{array}$ & $\begin{array}{l}\text { Jaswal et al. }{ }^{[20]} \\
\text { (skin smear) }\end{array}$ & Vijaikumar et al. ${ }^{[15]}$ (nerve aspirate) \\
\hline BB & & & $\begin{array}{l}\text { Fair cellular yields, } \\
\text { poorly cohesive } \\
\text { granuloma composed } \\
\text { of an admixture of } \\
\text { epithelioid cells and } \\
\text { macrophages, few } \\
\text { lymphocytes infiltrating } \\
\text { the granulomas. BI 1-2+ }\end{array}$ & $\begin{array}{l}\text { Fair cellular aspirate } \cdot \text { Mixed cellularity of } \\
\text { predominantly nonfoamy macrophages, } \\
\text { moderate number of epithelioid } \\
\text { cells and lymphocytes. Macrophage } \\
\text { granuloma } \mathrm{BI} 2-3+\text {. }\end{array}$ \\
\hline $\mathrm{BL}$ & $\begin{array}{l}\text { Moderate cellularity, singly } \\
\text { dispersed macrophages } \\
\text { with no epithelioid cells. } \\
\text { Numerous lymphocytes } \\
\text { diffusely scattered along } \\
\text { with macrophages. BI 3-4+ }\end{array}$ & $\begin{array}{l}\text { Moderate cellularity, singly } \\
\text { dispersed macrophages } \\
\text { with no epithelioid cells. } \\
\text { Numerous lymphocytes } \\
\text { diffusely scattered along with } \\
\text { macrophages. BI 3-4+ }\end{array}$ & $\begin{array}{l}\text { Moderate cellularity, } \\
\text { singly dispersed } \\
\text { macrophages with } \\
\text { negative images, } \\
\text { no epithelioid cells, } \\
\text { numerous lymphocytes } \\
\text { diffusely admixed with } \\
\text { macrophages. BI 3-4+ }\end{array}$ & $\begin{array}{l}\text { Fair cellular aspirate } \cdot \text { Predominantly } \\
\text { lymphocytes and moderate number of } \\
\text { foamy macrophages. BI. } 4-5+\text {. }\end{array}$ \\
\hline LL & $\begin{array}{l}\text { Heavy cellularity, numerous } \\
\text { foamy macrophages in } \\
\text { fatty background with a few } \\
\text { lymphocytes. BI 5-6+ }\end{array}$ & $\begin{array}{l}\text { Heavy cellularity, numerous } \\
\text { foamy macrophages in } \\
\text { fatty background with a few } \\
\text { lymphocytes. BI 5-6+ }\end{array}$ & $\begin{array}{l}\text { Heavy cellularity, } \\
\text { numerous foamy } \\
\text { macrophages in } \\
\text { fatty background } \\
\text { with intracellular and } \\
\text { extracellular negative } \\
\text { images, few lymphocytes. } \\
\text { BI 4-6+ }\end{array}$ & $\begin{array}{l}\text { Fair to poor cellular } \\
\text { aspirate Predominantly foamy } \\
\text { macrophages and few lymphocytes } \cdot \mathrm{BI} \\
6^{+}\end{array}$ \\
\hline
\end{tabular}

\section{Discussion}

The Ridley-Jopling (RJ) classification is used currently for classifying leprosy, which is based on clinical, bacteriological, immunological, and histological parameters ${ }^{[5-8]}$ It divides the leprosy spectrum into 'five' clinical and histological groups. Use of the RJ scale in the classification of leprosy helps in understanding the immunology of the patient to know the prognosis and possible complications. Ridley used ZN stain in 1989, to study the cytological material in leprosy cases ${ }^{[9] . ~ I n ~}$ 1994, Singh et al used FNAC to diagnose 30 leprosy cases including a case of nodular lepromatous leprosy ${ }^{[10]}$ using same technique..$^{[4]}$

It is proved in many studies that FNAC of sensory cutaneous nerve helps in detection of leprotic inflammation especially granulomas and lepra bacilli. ${ }^{[11-17]}$ Schwann cells arranged in fascicles could be seen along with granulomas. ${ }^{[13]}$ These cytological features of nerve aspirates also helps in the categorization of leprous neuritis along the Ridley-Jopling scale. ${ }^{[11,14,15]}$ Vijaikumar et al. studied cases with nerve involvement in leprosy and classified leprous neuritis into paucibacillary (PB), borderline borderline (BB), borderline lepromatous (BL), and polar lepromatous leprosy (LL) types. ${ }^{[15]}$ (Table-5) describes the RidleyJopling classification as given by different authors.

The accuracy of cytological classification along the RidleyJopling spectrum in nerve aspirate was found in $92 \%$ cases.
${ }^{[15]}$ However, a negative aspirate does not entirely rule out leprosy. ${ }^{[15]}$ A strong concordance in tuberculoid $(90 \%)$ and in lepromatous $(93.7 \%)$ cases has been documented. Mid-borderline cases of leprosy show a problem in proper diagnosis. ${ }^{[17]}$ Correlation of clinical diagnoses with FNAC examination has revealed varying results in different studies. In the present study, we were able to classify all nerve aspirates in 19 cases according to R-J criteria. We could observe organized granulomas as reported by Singh et al ${ }^{\left[{ }^{[4]}\right.}$ We did however, notice a very high correlation between clinical diagnoses and FNAC in all types of leprosy. We could not differentiate between TT and BT leprosy in four cases as reported by Singh et al.$^{[4]}$. Correlation was also high in BL and LL types where there were scanty cellular infiltrates and more foamy macrophages. Thus, it was possible to distinguish tuberculoid types by the presence of epithelioid cells and lepromatous types by the presence of lymphocytes and foamy macrophages. Singh et al. opined that cytological features of LL showed negative images of M. leprae on MGG-stained smears, which were later confirmed by AFB staining, ${ }^{[4]}$ and we could find the same in one case in the present study. Predominant lymphocytes are seen in cytology smears in the borderline types of the disease. In this study also, we found the largest number of lymphocytes in BL cases.

Singh et al. ${ }^{[4]}$ in 1995 attempted the cytological diagnosis and classification of leprosy and found $100 \%$ cytohistological concordance. Rao et al. ${ }^{[18]}$ also evaluated the utility of 
FNAC in the classification of leprosy and found 90\% concordance in cases of tuberculoid leprosy and $93.75 \%$ concordance was observed in lepromatous leprosy. They, however, observed difficulty in differentiating tuberculoid leprosy (TT) from borderline tuberculoid leprosy (BT) and borderline lepromatous leprosy (BL) from lepromatous leprosy (LL) on cytology. In this study, similar problem was seen in differentiating TT and BT cases.

\section{Conclusion}

Sensory cutaneous nerve FNAC is a quick \& safe procedure, which can be done routinely as an outdoor procedure in the evaluation of leprosy patients. Not only it is useful in diagnosis of PNL, but also in patients having concomitant skin \& nerve involvement. It is a sensitive tool for classifying the nerve lesions as per the Ridley-Jopling classification. It is also useful in patients with relapse.

\section{Reference}

1. Alexander J., Mc Adam, Milner DA, Sharpe AH. Infectitious diseases. In: Kumar, Abbas, Aster editors. Robbins and Cotran Pathologic basis of disease. 9 th edition Saunders/ Elsevier, Philadelphia 2014:377

2. E. Wilder-Smith, "Diagnosis of pure neuritic leprosy," Neurological Journal of South East Asia 2002;7: 61-63

3. Prasoon D, Mandal SK, Agrawal P. Sensory cutaneous nerve fine-needle aspiration in Hansen's disease: A retrospective analysis of our experience. J Cytol 2015;32:170-75.

4. Singh N, Bhatia A, Gupta K, Ramam M. Cytomorphology of Leprosy across the Ridley Jopling spectrum. Acta Cytol 1996;40:719-23.

5. Jopling WH, McDougall AC. Definition, epidemiology and world distribution. In: Jopling WH, McDougall AC, editors. Handbook of Leprosy. 5 th ed.CBS Publishers, New Delhi 1996:1.

6. Noordeen SK. The epidemiology of leprosy. In: Hastings RC, Opromolla DVA editors.Leprosy 2 nd ed. Churchill Livingstone, London 1994:29-45.

7. WHO Expert committee on leprosy 1988 Sixth report. Technical Report Series 768, Geneva: World Health Organization.
8. Ridley DS, Jopling WH. Classification of leprosy according to immunity: A five group system. Int J Lepr 1966;34:255-73.

9. Ridley MJ. The cellular exudate: Mycobacterium leprae relationship and the critical reading of slit smears. Lepr Rev 1989;60:229-40.

10. Singh N, Arora VK, Ramam M. Nodular lepromatous leprosy: Report of a case diagnosed by FNA. Diagn Cytopathol 1994;11:373-5.

11. Siddaraju N, Yaranal PJ, "Use of fine needle aspiration cytology in leprotic lesions: a report of 4 cases," Acta Cytologica 2007;51: 235-238

12. Theuvenet WZ, Miyazaki N, Roche PW, and Shrestha I, "Cytological needle aspiration of the nerve for the diagnosis of pure neural leprosy," International Journal of Leprosy $1993 ; 61: 597-599$

13. Jayaseelan E, Shariff S, Rout P, "Cytodiagnosis of primary neuritic leprosy," International Journal of Leprosy and Other Mycobacterial Diseases 1999;67: 429-434

14. Siddaraju N, Sistla SC, Singh N et al., "Pure neuritic leprosy with nerve abscess presenting as a cystic, soft tissue mass: report of a case diagnosed by fine needle aspiration cytology," Diagnostic Cytopathology 2009;37:355-8

15. Vijaikumar M, D'Souza M, Kumar S, Badhe B, "Fine needle aspiration cytology (FNAC) of nerves in leprosy," Leprosy Review 2001;72:171-178

16. Singh N, Malik A, Arora VK, Bhatia A, "Fine needle aspiration cytology of leprous neuritis," Acta Cytologica 2003;47: 368-372

17. Rao IS, Singh MK, Datta SK, Pandhi RK, Kapila K. "Utility of fine-needle aspiration cytology in the classification of leprosy," Diagnostic Cytopathology 2001;24:317-321

18. Prasad PV, George RV, Kaviarasan PK, Viswanathan P, Tippoo R, Anandhi C, "Fine needle aspiration cytology in leprosy," Indian Journal of Dermatology, Venereology and Leprology 2008;74:352-356

19. Jaswal TS, Jain VK, Jain V, Singh M, Kishore K, Singh S "Evaluation of leprosy lesions by skin smear cytology in comparison to histopathology," Indian Journal of Pathology and Microbiology 2001;44:277-281

*Corresponding author:

Dr Kishori M. Panda, Prof. of Pathology, Dept of Pathology, Govt Medical College, Raigarh, Chhattisgarh, India

Phone: +91 8763874020

Email: drkishoripanda@gmail.com

Financial or other Competing Interests: None.

Date of Submission : 22.11.2016

Date of Acceptance : 26.12.2016

Date of Publication : 07.04.2017 